\title{
Connexin 26 Gene Anomaly
}

National Cancer Institute

\section{Source}

National Cancer Institute. Connexin 26 Gene Anomaly. NCI Thesaurus. Code C84650.

Cong enital deafness caused by mutations in the gene GJB2 (deafness gene). 